\title{
THE GREAT DIVIDE Literacy, Nationalism, and the Communist Collapse
}

\author{
By KEITH DARDEN and ANNA GRZYMALA-BUSSE*
}

\section{INTRODUCTION}

W THY do some governing parties, closely associated with a collapsed authoritarian regime, nonetheless retain power and continue to govern? This paradoxical outcome occurred in 45 percent of countries of the former Soviet Union and its satellites. In some of these countries the first free elections returned the Communist Party to rule, while in others unreconstructed communists retained power and free elections were never held. In the remaining 55 percent, however, communist parties lost the first free elections and exited power completely.

In this article, we seek to explain these patterns of communist exit, which has spawned both empirical and theoretical controversies. The communist exit in the first free elections has been strongly correlated with subsequent democratic consolidation, successful economic reforms, and patterns of political party competition. ${ }^{1}$ Communist persistence, by contrast, resulted in "democracy with adjectives": (1) quasidemocratic systems that hold elections but do not foster competition or representation and (2) the rise of antireform coalitions that extract private benefits from the state and sabotage reforms. ${ }^{2}$

\footnotetext{
*The authors are listed alphabetically and share responsibility. This paper was first presented at the annual meeting of the American Political Science Association, Washington, D.C., 2005. We are grateful to Stephen Hanson, Jeff Kopstein, Grigore Pop-Eleches, the participants of faculty workshops at Duke University and the University of Michigan, and the three anonymous reviewers, for their very helpful comments. We would like to thank Shale Horowitz and David Reilly for sharing their data.

${ }^{1}$ M. Steven Fish, "The Determinants of Economic Reform in the Post-Communist World," East European Politics and Societies 12 (Winter 1998); Valerie Bunce, "The Political Economy of Postsocialism," Slavic Review 58 (Winter 1999); Herbert Kitschelt, "Accounting for Postcommunist Regime Diversity: What Counts as a Good Cause?" in Grzegorz Ekiert and Stephen Hanson, eds., Capitalism and Democracy in Central and Eastern Europe (Cambridge: Cambridge University Press, 2003).

${ }^{2}$ Steven Levitsky and Lucan Way, "The Rise of Competitive Authoritarianism," Journal of Democracy 13 (April 2002); Joel S. Hellman, "Winner Take All: The Politics of Partial Reform in Postcommunist Transitions," World Politics 50 (January 1998).
} 
At the same time, considerable criticism of the communist exit as an explanation for subsequent trajectories has emerged. First, Herbert Kitschelt, in particular, has charged that accounts focusing on the communist exit as a main explanatory variable suffer from excessive causal proximity, leading to an explanation that "yields little insight into the causal genealogy of a phenomenon." ${ }^{3}$ His critique begs a significant question: if the communist exit is so highly correlated with favorable outcomes, how do we account for the exit? Second, the mechanisms of this influence on economic and democratic outcomes have been difficult to pinpoint. Does the communist exit act as an independent causal factor that eliminates a source of antireformist sentiment and thus promotes greater elite consensus? Is it a simple symptom of deeper readiness for democracy and the free market or a necessary but not sufficient condition for subsequent reforms? Third, there has been little explanation of the reasons behind the communist exit, or how those reasons might themselves relate to postcollapse outcomes. This shortcoming has led to the criticism that, much as with the communist collapse itself, political science has focused on the wrong set of explanatory factors and mechanisms. One striking omission, for example, is a theory of one-party rule and the factors that could sustain its efficacy and even its legitimacy. ${ }^{4}$

The critical question underlying all these controversies is why communist rule ended in such divergent outcomes. Why, that is, was there communist exit from power in some countries but not in others? We argue that the ultimate roots of the explanation lie in precommunist schooling, which fomented and fostered nationalist ideas that led to the delegitimation of communist rule. The exit itself was the culmination of decades of nursed nationalist grievances, invidious comparisons, and carefully sustained mass hostility to the communist project as a foreign and inferior imposition. Section II reviews and tests the competing explanations. Section III examines the patterns of schooling. Section IV presents an alternative model that establishes a causal chain linking the introduction of mass schooling, subsequent ideas about the nation and its legitimate authority, the rise of anticommunist opposition, and the communist exit. As a result, some countries were much less hospitable to communism, more likely to kindle an opposition, and more likely

\footnotetext{
${ }^{3}$ Kitschelt (fn. 1).

+ Stathis Kalyvas, "The Decay and Breakdown of Communist One-Party Regimes," Annual Review of Political Science 2 (1999); Timur Kuran, "Now out of Never: The Element of Surprise in the East European Revolution of 1989," World Politics 44 (October 1991).
} 
to promote the kind of communist party that could and would leave. Section V concludes.

\section{Existing Explanations of the Communist Exit}

The literature on both the collapse of the communist regimes and the transitions that followed provides us with several competing explanations for the variation in the communist exit. These locate the forces behind the communist exit along a temporal continuum that begins with long-standing structural forces, such as geography, moves through the legacies of the precommunist era, and ends with the immediate causes of the communist collapse, such as the strength of the anticommunist opposition.

One prominent explanation for postcommunist trajectories focuses on structural factors, the favorable geopolitical settings that placed some of these countries in the Western Christian orbit, with its Enlightenment tradition, potential for trade, and diffusion of democratic ideas. One manifestation of this influence is the remarkable correlation that exists between proximity to the West (defined as the geographic distance between state capitals and either Vienna or Berlin) and the favorable configuration of communist exit, democratic reforms, and market liberalization, as Kopstein and Reilly 2000 demonstrate. ${ }^{5}$ Such settings allowed for the favorable influence of international organizations, "not so much of actual EU or NATO membership as of anticipated membership. These divergent, externally induced incentives are part of what accounts for differences in institutional reform, state behavior, and popular discourse in the countries of postcommunist Europe." After all, the nearest neighbors were also the objects of the most intense focus of the EU and other West European initiatives, and communism may have appeared less desirable if one's neighboring noncommunist points of reference were Germany and Austria rather than Afghanistan and Iran. Geographic proximity had also earlier fostered a sense of "belonging" to Europe.

A second influential approach examines the legacies of precommunist development and the ways in which the political experiences of the in-

${ }^{5}$ Jeffrey S. Kopstein and David A. Reilly, "Geographic Diffusion and the Transformation of the Postcommunist World," World Politics 53 (October 2000); Anna Grzymala-Busse and Pauline Jones Luong, "Reconceptualizing the State: Lessons from Post-Communism," Politics and Society 30 (December 2002).

${ }^{6}$ Kopstein and Reilly (fn. 5), 25. 
terwar era shaped the politics of the communist years and beyond. ${ }^{7}$ In the classic "modernization" account, wealth, industrialization prior to statehood, and overall levels of economic development are critical to the development of democracy and to the maintenance of regime stability. ${ }^{8}$ Considerable disparities persisted here in the communist era. Even though East Central Europe has been characterized as a backward periphery relative to Western Europe, ${ }^{9}$ its development levels were always higher than in Central Asia, for example. The communist exit, therefore, could be a function of precommunist economic development and, more broadly, of modernization.

In a similar account, the length of the prewar democratic experience and the political configurations that dominated it translate into distinct communist regime types. The resulting typology of communist regimes comprises bureaucratic-authoritarian, national-accommodative, and patrimonial systems. ${ }^{10}$ The first type, built on interwar working-class parties and a preexisting professional bureaucracy, results in a configuration of weak communist insiders, unable to forestall their own replacement during the communist collapse. At the opposite end of the spectrum, patrimonial communism, built on authoritarian regimes and nonprofessional bureaucracies, privileges the communist insiders and allows them to hold on to political and economic power. One prediction is that the longer the democratic and legal-rational experience prior to the onset of communism, the greater the likelihood of a communist exit.

Finally, the most temporally immediate explanation for the communist exit is the strength of the anticommunist opposition in the waning years of the communist regimes. As several scholars of regime transi-

${ }^{7}$ George Schöpflin, Politics in Eastern Europe (Oxford: Blackwell, 1993); Grzegorz Ekiert, "Democratic Processes in East Central Europe: A Theoretical Reconsideration," British Journal of Political Science 21, no. 3 (1991); Ken Jowitt, A New World Disorder (Berkeley: University of California Press, 1991); Ekiert and Hanson (fn. 1); Beverly Crawford and Arend Lijphart, "Enduring Political and Economic Change in Post-Communist Eastern Europe: Old Legacies, New Institutions, Hegemons, Norms and International Pressures," Comparative Political Studies 28, no. 2 (1995).

${ }^{8}$ Seymour Lipset, Political Man: The Social Basis of Politics (New York: Doubleday and Company, 1960); Daniel Lerner, The Passing of Traditional Society: Modernizing the Middle East (Glencoe, Ill.: Free Press, 1958); Alexander Inkeles, Becoming Modern: Individual Change in Six Developing Countries (Cambridge: Harvard University Press, 1969); Karl W. Deutsch, "Social Mobilization and Political Development," American Political Science Review 55 (September 1961); see also Adam Przeworski, Michael E. Alvarez, Jose Antonio Cheibub, and Fernando Limongi, Democracy and Development: Political Institutions and Well-being in the World, 1950-1990 (New York: Cambridge University Press, 2000).

${ }^{9}$ Andrew C. Janos, East Central Europe in the Modern World: The Politics of the Borderlands from Pre to Past-Communism (Stanford, Calif.: Stanford University Press, 2000).

${ }^{10}$ Herbert Kitschelt, Zdenka Mansfeldová, Radoslaw Markowski, and Gábor Tóka, Post-Communist Party Systems (Cambridge: Cambridge University Press, 1999). 
tions have noted, the strength of the opposition (and its constituent radicals and moderates) affects not only the likelihood of negotiations with an authoritarian government but also its outcome. ${ }^{11}$ The more powerful the opposition, the more likely is communist exit. Conversely, as Andrew Janos argued, "because it was rooted in the communalism and paternalism of Byzantine Orthodoxy, communism resonated far more positively in the Orthodox societies of the southeast, than in the legalistic, contract societies of the northwest tier." ${ }^{12}$ The implication here is that cultural receptiveness to communism underlies the patterns we observe and either promotes the rise of the opposition or sustains communist rule. ${ }^{13}$

While all of these explanations offer compelling accounts, they face two challenges. First, many of the accounts tend to rely on powerful correlations, rather than on clearly specified mechanisms by which the legacies of the past, for example, translate into outcomes decades later. Second, these accounts tend to address national-level variation: therefore, they cannot as easily explain the differences among the countries emerging from the former Soviet Union or the intranational diversity in support of the communist party. Yet these are as intriguing and as potentially important for theory building as are their national-level counterparts. As several scholars have noted, pockets of subnational authoritarianism can coexist with democratic national governments, ${ }^{14}$ producing very divergent regimes within the same nation-state.

More specific problems arise with the individual explanations. One complication with an emphasis on geographic factors is that some coun-

${ }^{11}$ Samuel Huntington, The Third Wave (Norman: University of Oklahoma Press, 1991); Laszlo Bruszt and David Stark, "Remaking the Political Field in Hungary," Journal of International Affairs 46 (Summer 1992). For the negotiations, see Jon Elster, ed., Round Table Talks and the Breakdown of Communism (Chicago: University of Chicago Press, 1997). See also Pauline Jones Luong, Institutional Change and Political Continuity in Post-Soviet Central Asia (Cambridge: Cambridge University Press, 2002); John Ishiyama, "Transitional Electoral Systems in Post-communist Eastern Europe," Political Science Quarterly 112 (Spring 1997); Thomas Remington and Steven Smith, "Institutional Design, Uncertainty, and Path Dependency during Transition," American Journal of Political Science 40 (October 1996); Patrick O'Neil, "Presidential Power in Post-communist Europe: The Hungarian Case in Comparative Perspective," Journal of Communist Studies 9 (September 1993); Timothy Frye, "A Politics of Institutional Choice: Post-communist Presidencies," Comparative Political Studies 30 (October 1997).

${ }^{12}$ Janos (fn. 9), 326.

${ }^{13}$ An excellent analysis of these arguments is in Grigore Pop-Eleches, "Which Past Matters? Communist and Pre-Communist Legacies and Post-Communist Regime Change" (Paper presented at the annual meeting of the American Political Science Association, Washington, D.C., September 1-4, 2005).

${ }^{14}$ Richard Snyder, "After the State Withdraws: Neoliberalism and Subnational Authoritarian Regimes in Mexico," in W. Cornelius, T. Eisenstadt, and J. Hindley, eds,, Subnational Politics and Democratization in Mexico (La Jolla: Center for U.S.-Mexican Studies, University of California, San Diego, 1999); Levitsky and Way (fn. 2); Robert Mickey, "Paths out of Dixie: The Democratization of Authoritarian Enclaves in America's Deep South, 1944-1972" (Book manuscript, Department of Political Science, University of Michigan, 2006). 
tries were considerably more pro-West than their. geographic location would seem to suggest: Estonia, Latvia, and Lithuania are all farther from Western capitals than Belarus, for example. Nor can geography explain the differences in achieving a "return to the West." How, that is, did geographic or cultural affinities translate into domestic political action. Moreover, the mechanisms of the affinity for Europe remain underspecified. Integration into specific regional and international organizations is an unlikely candidate: neither the EU nor NATO offered any serious prospects for membership until many years after the communist exit and the initial democratic and market reforms. ${ }^{15}$ In East Central Europe, when even the most ardent reformists spoke of a "return to Europe," they were referring to a normalcy defined by the lack of Soviet imperial interference and not to anticipated membership in specific international structures. Further, these sentiments did not break cleanly along geographic lines. Thus, European Serbians kept their communist party in power, while non-European Georgians rapidly dispensed with theirs. The desire to "join the West" or "return to Europe" was a significant motive and clustered geographically, but its roots do not lie in location alone. We thus need a better account of the mechanism underlying the desire to "return to Europe."

The mechanisms by which precommunist bureaucratic development and regime types translate into the communist exit are similarly underspecified. Temporal distance should not be conflated with causal depth. What, for example, are the causal links between a professional interwar bureaucracy and the weakness of communist insiders at the time of the communist collapse? There is little question that the precommunist development of a rational bureaucracy and direct rule distinguishes the communist and postcommunist development of many Central European countries from that of Central Asian states, where the Soviet Union was the first to bring any bureaucracy to nomadic societies. However, it is not clear why these differences would lead to the rejection of communist parties. Indeed, one could easily argue that the superior bureaucracy made communism more rational, efficient, and competent and that its bureaucratic legacy should have bolstered rather than undermined the legitimacy of communism. Moreover, having the right bureaucratic legacy was not a necessary condition; otherwise patrimonial Moldova, Armenia, and Georgia would have kept their communist parties in power.

\footnotetext{
${ }^{15}$ Thus, the EU was content to conduct bilateral agreements with postcommunist countries; membership as a feasible option did not even enter the discussion until 1995 and the Bosnia conflict.
} 
The strength of the anticommunist opposition movement as an explanatory variable explains both too much and too little. On the one hand, it is so strongly correlated with the communist exit that the possibility the two are part of the same phenomenon cannot be discounted. Once again, if we take warnings of excessive causal proximity seriously, we ought to beware of positing such powerful causal relationships between events that are so temporally close together. On the other hand, this explanation requires that we identify the determinants of a strong opposition: what are they, and do they explain the communist exit as well? ${ }^{16}$

A better, alternative explanation of the communist exit is therefore needed, one that accounts both for the immediate impetus for the exit and for its facilitating conditions. It should also provide a mechanism through which the communist exit becomes feasible and likely. If we turn to the precommunist past, we need to specify precisely which factors and processes made some societies less hospitable to communism on both the individual and the collective level, more likely to foment opposition, and more likely to foster the kind of ruling party that could and would leave power. A country's location and "neighborhood" by itself is unlikely to influence either the popular opposition or the legitimacy of communist rule. Prewar democratic statehood is a more likely candidate, since it may very well engender memories of noncommunist governance and the subsequent identification of communism as an "abnormal" form of governance. Finally, the development of anticommunist opposition itself needs explaining, since it is analytically and empirically so close to the communist exit.

One of the most striking aspects of the anticommunist opposition was its fusion with nationalism. Opposition movements claimed to be rescuing the nation from the grasp of an alien, imposed, and illegitimate communist regime. As Valerie Bunce argues, "The diffusion of the national idea served as the mechanism for opposition elites to confront imperial domination by seeking states and regimes of their own making." begs the questions of how and why these mass sentiments varied across the region and of which mechanisms link those beliefs-largely historical in origin-to contemporary events.

Although the development of nationalism has been linked to many tools of the modern state, the clearest mechanism for the transmission

\footnotetext{
${ }^{16}$ Bunce (fn. 1) and Janos (fn. 12) identified the rise of the opposition with prior statehood and the linking of the state project with liberalism.

${ }^{17}$ Bunce, "The National Idea: Imperial Legacies and Post-Communist Pathways in Eastern Europe," East European Politics and Societies 19 (Summer 2005).
} 
of a shared national identity and history is education. ${ }^{18}$ Although education is typically seen as part of a bundle of developments-urbanization, industrialization, income growth-due to the legacy of modernization theory, ${ }^{19}$ the role of education is causally and empirically distinct. Schooling provides the one clear channel for the deliberate and systematic inculcation of a set of values..$^{20}$ And the critical aspect of mass literacy is its timing: the national ideas instilled in a population during the first round of mass schooling-when a community first shifts from an oral to a literate mass culture-are durable, and the first schooled generation will transmit those values in ways that previous or subsequent cohorts do not, as we will see. ${ }^{21}$

We therefore focus on a historical legacy that predates not only communism but also, in several cases, nation-states; the legacy includes the timing of mass schooling and the nature of its national content. The communist exit could not have occurred without mass opposition to the regime- and that opposition in turn rested on notions of statehood and legitimate governance first inculcated by mass schooling. Attaining literacy under a noncommunist regime led to the transmission of a national identity separate from, and often directly opposed to, the communist regimes. Precommunist schooling thus lowers the magnitude of support for the communist party and increases the likelihood that widespread opposition to the communist party will arise. We therefore hypothesize that the communist exit is more likely to occur where literacy preceded the onset of communism.

The extent and content of mass literacy for the region are shown in Appendix 1. To establish the basic correlations and to test the rival hypotheses, we turn to straightforward statistical analyses that compare the impact of precommunist schooling on the communist exit with the influence of economic development, years of precommunist democratic statehood, and regional effects, including distance to the West. (The full operationalization and coding of these variables is included in Appendix 2.)

The findings support the claim that where precommunist schooling was firmly established and literacy was widespread, the populations were more likely to vote the communists out of power at the first avail-

${ }^{18}$ Ernest Gellner, Nations and Nationalism (Ithaca, N.Y.: Cornell University Press, 1983); E. J. Hobsbawm, Nations and Nationalism since 1780 (New York: Cambridge University Press, 1990), chap. 3; Barry Posen, "Nationalism, the Mass Army and Military Power," International Security 18 (Autumn 1993).

${ }^{19}$ Deutsch (fn. 8); Lipset (fn. 8); Inkeles (fn. 8); Lerner (fn. 8).

${ }^{20}$ Sylvia Scribner and Michael Cole, "Cognitive Consequences of Formal and Informal Education," Science 182 (November 9, 1973).

${ }_{21}$ Keith Darden, "Mass Schooling and the Formation of Enduring National Loyalties" (Book manuscript, Department of Political Science, Yale University, 2007). 


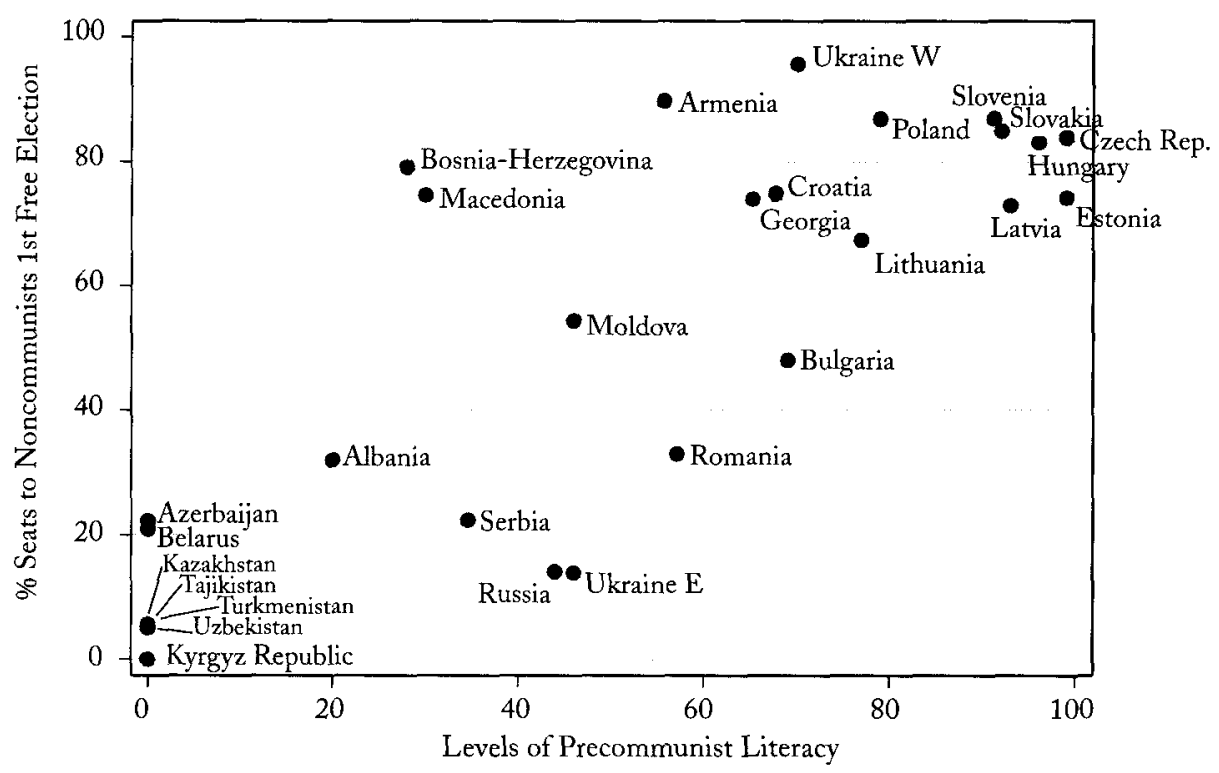

FIGURE 1

Precommunist Schooling and Share of Seats to Noncommunist Parties in the First Free Postcommunist Elections

able opportunity. As shown in the simple scatterplot of Figure 1, there is a clear linear relationship between the percentage of the population that was literate at the onset of communism and the defeat of the communists in the first free elections. ${ }^{22}$ In all countries with high levels of precommunist literacy, the communists were soundly defeated in the first free elections.

To conduct some basic statistical tests of our hypothesis, we chose a simple cross-sectional oLS regression as our estimation procedure and applied it to the universe of postcommunist cases. ${ }^{23}$ The findings in

${ }_{22}$ Only Macedonia and Bosnia-Herzegovina, both with low levels of education prior to 1945 , diverge from this general pattern. These two cases will require further research; given the high level of decentralization in the Yugoslav school system, we currently lack sufficient data on the content of schooling in these provinces under communism.

${ }^{23}$ With one notable exception, Ukraine, our units were the current countries and the historical data are for the population that lived within the current boundaries. Given the significant regional differences in the content and extent of schooling prior to communism, we created two units out of Ukraine, one for the three provinces that made up Austrian Galicia and another for the remaining provinces. 
TABLE 1

Share of Seats to Noncommunist Parties in the

First Free Postcommunist Elections

(OLS REGRESSION, BOOTSTRAPPED STANDARD ERRORS; 50 REPLICATIONS)

\begin{tabular}{lccccc}
\hline & Model 1 & Model 2 & Model 3 & Model 4 & Model 5 \\
\hline Precommunist literacy rate & $.849^{* * *}$ & $.960^{* * *}$ & $.826^{* * *}$ & $.777^{* * *}$ & $.669^{* *}$ \\
& $(.087)$ & $(.107)$ & $(.156)$ & $(.211)$ & $(.243)$ \\
Precommunist urbanization & & -.761 & -.614 & -.439 & -.457 \\
& & $(.432)$ & $(.458)$ & $(.527)$ & $(.398)$ \\
Years of prior democratic & & & .882 & .769 & .721 \\
$\quad$ statehood & & & $(.980)$ & $(.834)$ & $(.996)$ \\
East Central European & & & & 6.29 & \\
$\quad$ dummy & & & & $(9.27)$ & \\
Distance to West & & & & & -.007 \\
& 5.65 & 13.91 & 13.92 & 10.89 & 27.14 \\
Constant & $(7.10)$ & $(9.64)$ & $(10.95)$ & $(9.26)$ & $(18.40)$ \\
& 28 & 28 & 28 & 28 & 28 \\
N & .60 & .62 & .62 & .63 & .64 \\
Adj. r-squared & & & & & \\
\hline
\end{tabular}

$* * *(P>|z|)=.000 ; * *(P>|z|) \leq .01$

Table 1 confirm what is readily apparent from the scatterplot-that precommunist schooling alone accounts for over 80 percent of the variance (model 1).

Once we include precommunist literacy, the effects of urbanization wash out (model 2). In contrast to modernization theory, then, we find that "all good things" do not go together: the impact of schooling is independent both of prewar democratic statehood and of urbanization levels (one proxy for industrialization in precommunist countries). ${ }^{24}$ The possibility that literacy captures the effects of precommunist statehood and the advantages of national unity that it might confer are disconfirmed by model 3 , which includes a control for years of prior statehood. The inclusion of these variables, either individually or together, added nothing to improve the fit of the model; nor did it change the explanatory primacy of precommunist literacy. Finally, in contrast to the structural accounts, neither a dummy for East Central Europe (which would capture the effects of being outside of the Soviet Union) nor the distance to Western capitals captures any of the variation once included in the equation with precommunist literacy (models 4 and 5). 
All these results are robust to specifications of the communist exit either as votes for the opposition or as seats captured by noncommunists. Since there are no reliable, consistent, and comparable measures of historical wealth for the region, we did not use estimates of historical GDP as a proxy for precommunist modernization. ${ }^{25}$ Instead, we used several other proxies: percentage of population employed in agriculture, doctors per capita, and railroad density (kilometers of rail per square kilometer of territory). None of these was substantively or statistically significant, either alone or in combination with the other variables. The results confirm our initial finding, that indicators of economic development and modernization do not undermine the dominant impact of precommunist literacy. ${ }^{26}$

In short, structural/geopolitical factors and precommunist legacies (including those of modernization) explain less of the patterns of communist exit than mass literacy. This suggests that we may be capturing the unmeasured cultural differences that many scholars have attributed to "regional effects" or the "Soviet legacy." The identification of prior national schooling as the source of supposed "regional effects" is further borne out with more microlevel comparisons. The regional differences within the Soviet and Yugoslav cases bear out this conclusion. The differences between, for example, Ukrainian nationalist Lvov and its procommunist neighbor Zakarpatska, or between communist Western Belarus and nationalist Lithuania show the importance of precommunist cultural differences for postcommunist political trajectories.

While we recognize and acknowledge the potential problems associated with cross-sectional country-level statistical analyses with a relatively small number of observations, these findings are consistent with our hypotheses about the link between precommunist schooling and anticommunism. Further, this analysis suggests that nationalism, which modernization ought to have supplanted in favor of more secular understandings of societal interests, remained a driving force behind the rejection of communism.

Moreover, concerns about endogeneity (a problem endemic in crosssectional analyses of postcommunist data) are alleviated because the

\footnotetext{
${ }^{25}$ The widely used historical GDP data set by Angus Maddison is unfortunately incomplete and does not break down the data for the republics in the Soviet, Yugoslav, and Czechoslovak federations; Maddison, Monitoring the World Economy, 1820-1992 (Paris: OECD Development Centre, 1995). Much of these data are simply not available, especially in the areas under Soviet control, such as Central Asia. See David Good, "The Economic Lag of Central and Eastern Europe: Income Estimates for the Habsburg Successor States, 1870-1910," Journal of Economic History 54 (December 1994); and Michael Pammer, "Proxy Data and Income Estimates: The Economic Lag of Central and Eastern Europe," Journal of Economic History 57 (June 1997).

${ }^{26}$ Full results and the data set are available from the authors.
} 
primary variables of interest-precommunist schooling and postcommunist electoral outcomes - are so far apart in time. Given the radical changes that took place in this region between the onset of communism and its collapse, the fact that a precommunist variable could account for so much of the variation in a postcommunist outcome demands explanation.

\section{Correlating Mass Schooling and the Communist Exit}

What, then, were the patterns of mass schooling? To measure the extent to which the population has been schooled, our primary measure is the literacy rate, because by the turn of the twentieth century, virtually all education was taking place in schools. Typically, a literate citizen would have spent at least four years in school and been exposed to the standard history, literature, geography, and music curricula that shaped common national identities and political loyalties. The illiterate peasantry or herdsmen, by contrast, were typically fragmented into "islands of local customs and relationships, festivity and folklore, which were set apart from the rest of society by dialect and tradition, as well as by the limits on scale which oral communication inevitably imposes." 27 The rate of literacy thus marks the extent of schooling and the degree to which a standardized "high culture" and written history had become a common culture that was shared on a mass scale.

With respect to precommunist literacy and culture, postcommunist countries fall into three basic categories. In the first group are those with highly schooled populations and substantial national content in the schooling curriculum at the onset of the communist period: the Czech Republic, Estonia, Hungary, Latvia, Slovakia, Slovenia, Poland, Lithuania, Croatia, Romania, and the Western Ukrainian region of Galicia. All of these countries/regions had achieved over 70 percent literacy before communism. Most of these areas had already sustained universal primary education for several generations prior to communism and typically also had high rates of secondary education and wellestablished institutions of higher education.

The precommunist schooling in these countries was infused with national content. ${ }^{28}$ In the Habsburg provinces that became Hungary,

${ }^{27}$ James Sheehan, "What Is German History? Reflections on the Role of the Nation in German History and Historiography," Journal of Modern History 53 (March 1981), 8.

${ }^{28}$ For a useful contemporary overview of these cases published under the auspices of the League of Nations, see Jonathan French Scott, The Menace of Nationalism in Education (London: G. Allen and Unwin, 1926). On the general development of history and social studies in education, which at the time was highly infused with national and racial categories, see Aaron Benavot, Yun-Kying Cha, David Kamens, John W. Meyer, and Suk-Ying Yong, "Knowledge for the Masses: World Models and National Curricula, 1920-1986," American Sociological Review 56 (February 1991). 
the Czech Republic, Poland, Croatia, Slovakia, Slovenia, Romania, and Ukrainian Galicia this nationalist content was, in part, the legacy of a long-standing Habsburg policy of divide and rule-national antagonisms were cultivated in an effort to prevent challenges to the monarchy from coalescing. ${ }^{29}$ In the nineteenth century Vienna used school curricula to cultivate a new Ukrainian identity in Galicia to counter the active nationalism of the Poles and potential irredentism of the Russians, and similarly assisted the national development of the Romanians, Croats, and Slovaks to undermine the growing influence of Hungarian nobles (the Hungarians, in response, cultivated Serbian identity to divide the Serbo-Croats). ${ }^{30}$ Subsequently, the progressive decentralization of Habsburg control over educational content also created opportunities for new nationalist elites, particularly in Hungary, the Czech lands, and Poland, to build support for their claims to independent statehood. Even Croatia, the least educated of these countries, had crossed a 50 percent threshold of literacy by 1910, and its educational system had substantial national content. Thus, even under imperial rule, the curriculum had national content and stressed the cultivation of distinctive identities.

During the interwar period, these governments and the three Baltic states were using nationalist school curricula to build loyalty to the new states and to legitimate their territorial claims. Hungary, Romania, Bulgaria, the three Baltic states, and (by the 1930s) Poland created centralized, standardized school curricula and teacher training with a strong focus on nationalizing and homogenizing their populations. In the Czech and Slovak territories, the vast majority of schools cultivated the identity of the titular nationality of their respective provinces: schooling was decentralized, so the curriculum was often decided at the level of the school. ${ }^{31}$

Elsewhere, in Transcarpathia, there was no consistent policy to introduce national content in education, and a mix of Russophile Russian émigrés, Rusynophile intellectuals, and Ukrainian nationalists from neighboring Galicia provided the limited education that the province

\footnotetext{
${ }^{29}$ In the words of Francis II: "My people are strangers to one another, and so it is best. They do not take the same malady at the same time. In France, when the fever comes, it attacks you all the same day. I put the Hungarians in Italy and the Italians in Hungary. Each watches his neighbor. They do not understand each other and they detest each other. From their antipathy order is born, and from their reciprocal hatred, the general peace." Sarah E. Simons, "Social Assimilation I," American Journal of Sociology 6 (May 1901), 814.

${ }^{30}$ Robert A. Kann, The Multinational Empire: Nationalism and Reform in the Habsburg Monarchy, 1848-1918 (New York: Octagon Books, 1970); Charles Jelavich, South Slav Nationalism: Textbooks and Yugoslav Union before 1914 (Columbus: Ohio State University Press, 1980), 18-20; Paul Robert Magocsi, A History of Ukraine (Seattle: University of Washington Press, 1996), 407-15.

${ }^{31}$ Magocsi (fn. 30), 168.
} 
had achieved by 1938 , when it was occupied by Hungary. ${ }^{32}$ Yugoslavia's educational apparatus was so poorly funded that prior teachers, curricula, and many texts remained in place through the interwar years. ${ }^{33}$ This meant that regions with strong school systems and a history of education (Slovenia, Croatia, and Vojvodina) typically retained their literacy levels, whereas the less educated regions showed only marginal advancement. ${ }^{34}$ In all these cases, the explicit purpose of the mass education of the peasantry was to infuse them with new forms of national loyalty believed to be necessary to secure loyal bureaucrats, loyal soldiers, and loyal citizens. ${ }^{35}$

At the other end of the spectrum falls the second cluster of countries, those with little or no exposure to literate culture prior to communism. Albania, Azerbaijan, the five countries of Soviet Central Asia, Bosnia-Herzegovina, and Macedonia each had no more than 30 percent literacy when the communists took power. Prior to communism, these regions had little or no schooling and were marked by high levels of cultural heterogeneity and fragmented, localized identities and political loyalties attributed to traditional societies. ${ }^{36}$

The few literate residents were either national minorities or imperial administrators. In Azerbaijan and Central Asia those who could read and write were typically Russians or other nontitular nationalities. Of the non-Slavic populations of these regions, none but the Uzbeks had achieved even 5 percent literacy by 1920, when the Soviet Union began its literacy campaigns and conducted its first census in the region. In the tsarist empire, the limited schooling in Azerbaijan and Central Asia was almost exclusively in Russian and the cheap, popular reading materials of the time (lubok) were entirely Russocentric. ${ }^{37}$ Aside from a handful of Jadidist (pan-Turkic nationalist) intellectuals, the schooling and educational life of the region were entirely lacking in "national" content that would link the local cultures of the region to a claim to legitimate rule or sovereign rights. As late as 1909 Albania did not have

${ }^{32}$ Ibid., 177.

${ }^{33}$ Jelavich (fn. 30).

${ }^{34}$ In fact the slight improvement in literacy rates for Yugoslavia as a whole is probably attributable to the death of an older generation of illiterates rather than any significant improvements in education.

${ }^{35}$ Hobsbawm (fn. 18), chap. 3; Posen (fn. 18).

${ }^{36}$ Robert J. Kaiser, The Geography of Nationalism in Russia and USSR (Princeton: Princeton University Press, 1994), 44; Nicholas Vakar, Belorussia: The Making of a Nation (Cambridge: Harvard University Press, 1956); Loring Danforth, The Macedonian Confict (Princeton: Princeton University Press, 1995).

${ }^{37}$ Kaiser (fn. 36), 67; Ben Eklof, Russian Peasant Schools: Officialdom, Village Culture, and Popular Pedagogy, 1861-1914 (Berkeley: University of California Press, 1986). 
even a single teacher training school and the Albanian language had no standard alphabet. ${ }^{38}$ Even by the end of the interwar period, Albania had achieved only a meager 20 percent literacy rate and this training was almost entirely of a religious nature. The schooling that these regions eventually received would be under communist control.

In the remaining cases mass education was in the process of being established or varied considerably within the country, having been completed in some regions but hardly begun in others. In Romania, for example, an overall literacy rate of 57.1 percent in 1930 masked differences between Transylvania, with nearly full literacy and strong national content as in other Habsburg communities, and Bessarabia, where only 38 percent of the population could read and write. Serbia, similarly, had nearly full literacy in Vojvodina and in areas around Belgrade but exceptionally low rates of literacy in Kosovo, confirming "that the Serbian national program was not complete." 39

Russia, Ukraine, Belarus, and the interwar Moldovan ASSR (current Transdniestria) had all achieved moderate rates of literacy, and the youngest generation would have had nearly universal coverage in most of these provinces. ${ }^{40}$ These populations were schooled to believe, however, that they were part of a broader Russian nation, with a common past in Kievan Rus, comprising the Great Russians, the Lesser Russians (Ukrainians), and the White Russians (Belorussians). ${ }^{41}$ Hence, while the Slavic populations of Belarus and Ukraine had achieved moderate rates of schooling prior to communism, the schooling was Russian in language and focused on broader Russian and Orthodox unity.

Of the cases where mass schooling was initiated but full literacy was not yet attained prior to the communist period, the most interesting are Armenia and Georgia, where the content of schooling was nationalist, despite the fact that the main educational push was carried out when these territories were under Soviet control. Following the Bolshevik Revolution, Georgia and Armenia formed a separate independent Transcaucasian Confederation with Azerbaijan that lasted until 1920-21. During this brief time, both republics set up national primary school systems, with nationalist texts and teacher training. ${ }^{42}$ The Soviet

${ }^{38}$ Barbara Jelavich, History of the Balkans (Cambridge: Cambridge University Press, 1983), 88.

${ }^{39}$ Jelavich (fn. 30), 16.

${ }^{40} \mathrm{Jews}$, who were nearly all annihilated on the territory of Ukraine and Belarus during the Second World War and thus could have little effect on postcommunist trajectories, would have inflated the precommunist literacy statistics of these regions somewhat.

${ }^{41}$ Eklof (fn. 37)

${ }^{42}$ On Georgia, see Wladimir Woytinsky, La Démocratie géorgienne (Paris: Librairie Alcan Lévy, 1921), 266-70; and Karl Kautsky, Georgia: A Social-Democratic Peasant Republic, trans. H. J. Stenning (London: International Bookshops, 1921). 
government, according to Martin, following the annexation "boasted that Soviet power had deepened the national work begun" ${ }^{43}$ by precommunist nation-building governments. Teachers and curricula were retained, and by the time that the "Great Retreat" from this policy began in 1933 and especially by the "Great Purge" of $1937,{ }^{44}$ the populations of these territories were already schooled in an alternative pre-Soviet national curriculum. Thus, even according to the 1939 census, ethnic Georgians made up 72.2 percent of the teachers in the republic and 73.6 percent of the professors and researchers even though they were only 61.4 percent of the population of the republic. ${ }^{45}$ Similarly, ethnic Armenians constituted 84.2 percent of teachers and 88.5 percent of professors and researchers in the Armenian SSR, both in excess of their 82.8 percent share of the population as a whole. ${ }^{46}$

More important than the raw percentage of titulars, however, is the fact that the titular nationality had been educated in a fundamentally different way in Georgia and Armenia than it had been elsewhere in the USSR prior to World War II. As a result, even though Georgia and Armenia had literacy of less than 50 percent upon their incorporation into the USSR, these two countries preserved their pre-Soviet nationalist school curricula and teaching cadre into the early 1930s, when the population as a whole achieved nearly full literacy.

\section{Section IV. From Schooling to Anticommunism}

The processes linking mass schooling to broad-based nationalism unfolded via three mechanisms. First, schools brought mass literacy. Literacy meant that face-to-face communication was no longer required for the easy dissemination of ideas across time and space. It also dramatically increased a society's capacity to record and convey history, literature, and myth; the amount that could reliably be stored in books and accessed from them was much greater than what could be retained in memory. ${ }^{47}$ Mass literacy allowed the social communication among strangers that Deutsch, Anderson, and others have identified as a pre-

\footnotetext{
${ }^{43}$ Terry Martin, The Affirmative Action Empire: Nations and Nationalism in the Soviet Union, 19231939 (Ithaca, N.Y.: London: Cornell University Press, 2001), 15.

${ }^{44}$ It was a purge that, in Georgia, largely targeted teachers and the intelligentsia. Tamara Dragadze, Rural Families in Soviet Georgia (New York: Routledge, 1988), 185.

${ }^{45}$ USSR Census of 1939: Aggregate Statistics from the USSR Census of 1939 (Computer file, Toronto, University of Toronto, Centre for Research in East European Studies), Robert E. Johnson, producer (Toronto: University of'Toronto, Data Library Service [distributor], 1995), table 63b.

${ }^{46}$ Ibid., table $66 \mathrm{~b}$.

${ }^{47}$ Jack Goody, The Power of the Written Tradition (Washington, D.C.: Smithsonian Institution Press, 2000), 27.
} 
condition of nationalism. ${ }^{48}$ Education thus increased society's "carrying capacity" for transmitting, replicating, and sustaining nationalist ideas.

Second, and more important, mass schooling used the curriculum to convey nationalist ideas. Most schools in the late nineteenth and early twentieth century purveyed nationalist content in the basic subjects of literature, history, geography, and music and thereby inculcated a sense of patriotism in the children. As a result, the rise of nationalism in most European cases can be traced directly to changes in the education and socialization of the young and to the simultaneous introduction of nationalist content into school curricula. Prior to the development of mass schooling, education and socialization consisted of children imitating the rituals, mores, habits, skills, and beliefs of their parents or elders. ${ }^{49}$ This form of informal education was inherently conservative. Culture was predominantly learned-or replicated - through observation and experience. Nationalism, however, was a novel idea that could not be conveyed well through such traditional channels. It was not a set of ideas prevalent among the previous generation; and as an abstract, imaginary bond among a community of strangers, nationalism could not be learned through experience. It could, however, be learned in school. As the reading of school texts replaced the observation of experience as the primary form of instruction, children came to think and categorize the world more in terms of the general and the abstract than in terms of the practical categories based on experience. ${ }^{50}$ The nation and their place in it was one of the abstract categories that children acquired in school. ${ }^{51}$

${ }^{48}$ Karl W. Deutsch, Nationalism and Social Communication (Cambridge: MIT Press, 1953), 87, 101; Benedict Anderson, Imagined Communities (New York: Verso, 1991), 44-46.

${ }^{49}$ Scribner and Cole (fn. 20), 554-55.

${ }^{50}$ Considerable experimental evidence supports the notion of a direct causal relationship between schooling and abstract thought and reliance on general concepts not drawn from experience. See the discussion of these experiments in A. R. Luria, "Towards the Problem of the Historical Nature of Psychological Processes," International Journal of Psychology 6, no. 4 (1971); idem, Cognitive Development: Its Cultural and Social Foundations (Cambridge: Harvard University Press, 1976); Scribner and Cole (fn. 20); and especially idem, The Psychology of Literacy (Cambridge: Harvard University Press, 1981). As demonstrated most persuasively by the experiments conducted by Scribner and Cole (pp. 130-33), with the Vai tribe of Liberia, the shift toward abstraction is linked only to Western-style schooling (that is, curricular content), not to the development of literacy or written languages of the type of rote memorization typical of Islamic madrassas.

${ }^{51}$ In one of the few efforts to test the hypothesis linking schooling and nationalism systematically, Howard Schuman, Alex Inkeles, and David H. Smith, in their study of East Pakistan in the 1960s, found that even controlling for factors such as urbanization and occupation, literacy had a massive substantive impact on the likelihood that respondents would identify first and foremost as Pakistanis (rather than with their Bengali, regional, or village identities); Schuman, Inkeles, and Smith, "Some Social Psychological Effects and Noneffects of Literacy in a New Nation," Economic Development and Cultural Change 16 (October 1967). 
Third, this content was monitored and purveyed by a broad, national-institutional apparatus devoted to indoctrinating the younger generation in a common set of ideas. ${ }^{52}$ In each community a bounded, controlled setting was established. It was in this environment-the school-that a majority of children spent much of their waking life over a period of many years. Authority over the dissemination of ideas in this setting was strictly controlled by a teaching staff. The staff, in turn, was under the control of the state, educated in its central institutions, and teaching from a generally standardized curriculum. ${ }^{53}$ This curriculum and the broad nationwide educational apparatus that disseminated it conveyed a consistent national culture over an enormous territorial domain, typically within a single generation.

In short, mass schooling explains a critical element in the supply of nationalist ideas. A considerable institutional apparatus is required to convey an abstract, shared idea like common nationhood to masses of people who have little or no face-to-face interaction with one another. The rise of formal schooling accomplished this (1) by bringing a shift from oral, informal socialization to general training based on the written word and school texts, (2) by introducing nationalist content into school curricula, and (3) by disseminating this nationalist cultural message through titular-language teachers and standardized statewide institutions.

The mass schooling received by this first literate generation was critical, in that it "immunized" that generation against subsequent attempts to inculcate the populace with different notions of nation, such as those found under communist education. Once established, these ideas were sustained despite border shifts, the decimation of wars, and the migrations of populations. Thus, Germans living in Poland or in Czechoslovakia saw themselves as distinctly German. And Poles forced to migrate to the Soviet Union or the "Volga Germans" maintained their respective identities. ${ }^{54}$

As a result, ideas initially introduced through schooling came to be instilled in the popular culture and eventually accepted as common-

\footnotetext{
${ }^{52}$ The model, emulated by most countries in both Eastern and Western Europe, was the Prussian school system adopted in 1808 . The ideology justifying the nationwide system was the need to build a new set of shared ideas to legitimate state authority in the face of the breakdown of the old traditional order.

${ }^{53}$ On the importance of this modern "pyramid" of schooling for the development of nationalism, see Gellner (fn. 18), 34.

${ }^{54}$ The postwar demographic shifts had little impact on nationalist sentiments. Germans returned to Germany, Poles moved from Ukraine and Lithuania into the new borders of Poland, and so on. The forced migrations did not insert new populations with distinct linguistic or national identities into established national communities. The tragedy of the Holocaust further homogenized the ethnic composition of Poland, Hungary, and other countries.
} 
place truths. Unlike previous modes of ideational transmission such as church organizations, which rested on the authority of trained elites with cloistered knowledge, mass schooling embedded ideas in the community at large, making all members "authorities." 55 Schooling carried ideas directly into the household, and any schoolchild could replicate the history of the nation, could sing the national songs, recite the national poets, and explain the significance of dates and symbols of national importance. A society transformed by literacy was particularly suited to the rigors of underground subversion, solidarity, and perseverance. These identities were also robust to the enormous upheavals of war, genocide, and population transfers that surrounded World War II: the national identities were instilled in families and thus survived with family units as they were transferred and resettled hundreds of miles away. (Ironically, the increased population homogeneity in Poland, Czechoslovakia, and Hungary that followed World War II also meant greater homogeneity of anticommunist sentiment.)

Two caveats are important here. First, mass schooling and literacy were not necessary conditions for the spread of nationalism-nationalist ideas could also be conveyed through church pulpits or other forms of mass oral communication, if not as effectively or irreversibly. Second, schooling alone was not sufficient to foment nationalism; it had to be schooling with nationalist content. Nineteenth-century schooling included new subjects such as geography and history that served to inculcate ideas of nation and nationalism. Earlier, Protestant Reformers and Jesuit Counter-Reformers had employed schools in a battle for the minds of children in the seventeenth century, but such schooling resulted in strong attachments to a sectarian catechism rather than to different national identities. ${ }^{56}$ Nationalism and schooling become causally linked only when a nationalist curriculum was introduced in the nineteenth century. It was at that time that literacy began to spread to the populations of eastern Europe and parts of what would become the USSR. Hence, in the precommunist cases that we examine here, nationalism accompanied the rise of the school.

\section{From Nations to VALUES}

Notions of a shared national identity then provided standards for what would constitute legitimate rule-governments consonant with

${ }^{55}$ Gellner (fn. 18), 32.

${ }^{56}$ C. John Sommerville, The Discovery of Childhood in Puritan England (Athens: University of Georgia Press, 1992), chap. 9. 
national values that advance shared understandings of economic and political development. Both potential counterelites and citizens used three criteria in evaluating the legitimacy of communism. First, was communism a domestic development or was it the imposition of an occupying force? Second, was its sponsor, the Soviet Union, a historical enemy or a more friendly power? Third, and most important, did communism represent a political, cultural, and economic advancement for the nation, or was it an antimodern step backward? Put differently, was communism in keeping with religious, cultural, and economic national expectations?

Where national schooling existed prior to communist rule, these questions were answered in the negative. The communist regime was perceived to be an alien, inferior imposition by a suspect regional superpower. This is not to say that some local elites were not fervent communists who played a key role in establishing communist rule or that the values of socialism, such as guaranteed employment, social security, and egalitarianism, were rejected. But as both historical accounts and communist-era public opinion polls show, the communist regimes were not seen as legitimate. Instead, communist parties first battled popular resistance in establishing their rule and then battled apathy once it was established, while the plurality of society looked back with nostalgia to the precommunist era. ${ }^{57}$

Thus, after World War II, the Communist Party experienced success in free elections only in Czechoslovakia, where a strong local tradition of social democracy had existed prior to the war. ${ }^{58}$ This was largely the result both of a moderation in communist appeals and of the uncertain status of the newly regained Sudetenland..$^{59}$ As soon as the communists began the move to consolidate their power, however, they met with protest and criticism. In Slovakia the communists lost the 1946 elections by a wide margin. In Poland and in Hungary communism arrived with Soviet tanks, was imposed with the clear support of the Soviet Union and its occupying forces, and was never approved electorally.

\footnotetext{
${ }^{57}$ See in particular the chapters by Bela Zhelitski, John Micgiel, and Inessa Iazhborovoskaia, in Norman Naimark and Leonid Gibianskii, eds., The Establisbment of Communist Regimes in Eastern Europe, 1944-1949 (Boulder, Colo.: Westview Press, 1997). The few reliable communist-era public opinion polls tended to show a support for socialist values without support for the regime itself (in Poland, for example, roughly 70 percent of the students polled supported socialist values but rejected Marxism). In both the Czech Republic and Poland, these polls also show interest and glorification of the prewar era. Walter D. Connor and Zvi Gitelman, Public Opinion in European Socialist Systems (New York: Praeger, 1977), 45-178.

${ }^{58}$ The Communist Party won 38 percent in the Czech lands but far less in Slovakia.

${ }^{59}$ The Red Army and Soviet presence were seen as the main guarantee of border integrity in the Sudetenland.
} 
Even in Yugoslavia, where communism was "homegrown," it support was not ensured. ${ }^{60}$

Russia and then the Soviet Union were seen as enemies of both the nation and the national idea. This notion stemmed both from the wartime experiences of Soviet occupation (and in the case of Poland, the refusal to aid the anti-Nazi uprisings) and from the prewar teaching of history. The partial exceptions here are Bulgaria ${ }^{61}$ and to some extent Serbia: ${ }^{62}$ where nationalist schooling also included a heavily pro-Russian and then a pro-Soviet component, largely due to Russia's role in the liberation of these areas from Ottoman rule.

For countries that had tasted independent economic and cultural development in the interwar period, communism represented a step back from modernity and from national values. It was secular, whereas many of the national ideas of Poland, Hungary, Croatia, and Slovakia were closely aligned with the Catholic church. ${ }^{63}$ It was nominally antinationalist and cosmopolitan at a time when local national sentiments were intense. Finally, it entailed an industrial production profile that ignored local comparative advantages and pushed both standards of living and gross national products below prewar levels. For the petite bourgeoisie of Czechoslovakia, Slovenia, and Hungary, nationalization of property and the perception that economic policy now favored Soviet interests represented an economic disaster. ${ }^{64}$

These standards for what would constitute legitimate rule arose from a set of shared expectations about who would best serve national interests and about what constituted the bundle of cultural and economic goods, civic rights, and political responsibilities such a government ought to provide for its citizens. The existence of these standards then led to two sets of comparisons made throughout the communist era: with noncommunist neighbors and with the counterfactual for the communist countries - the imagined trajectories of development had communism not been imposed. As a result, where Central Asian republics saw de-

\footnotetext{
${ }^{60}$ The victorious Yugoslav partisans under Tito relied on the presence of the Soviet Army and its entrance into Belgrade in 1945, to ensure communist rule.

${ }^{61}$ The lower enmity to Russia in Bulgaria stems from the 1905 liberation of Bulgaria from Ottoman rule by the Russians.

${ }^{62}$ The Serbian Orthodox church claimed a kinship with its Russian Orthodox brethren.

${ }^{63}$ The most explicit example of this conflation is the Polish Black Madonna, both an object of religious veneration (pilgrimages, prayers) and the symbol of divine protection of Poland (credited with inspiring the resistance to the Swedish invasion in the seventeenth century and with the success of the Bolshevik War of 1920).

${ }^{64}$ For example, Hungarian postwar inflation was the worst the country had experienced. Similarly, industrialization plans in the Czech lands failed largely because the country was already industrialized, had few natural resources, and had been dependent on foreign trade, largely with Germany.
} 
velopment and enormous advances in the rights of women, economic growth, industrialization, and the building of national infrastructure, many of their East Central European counterparts saw a massive slide backward into oppression, economic stagnation, nationalization of markets, and national underdevelopment. In Poland the constant standard of reference was przedwojenny, or "prewar," an adjective used to describe lost excellence in everything from buildings to scouting associations to fruit preserves. In Hungary, Czechoslovakia, and Poland, scholars covertly calculated the economic costs of belonging to the Soviet sphere of influence and of having to engage in forced trade with the Soviet bloc on unfavorable terms, while their Slovenian and Croatian counterparts estimated the costs of subsidizing other republics in the Yugoslav federation. The comparisons were not favorable. Even as these societies became more industrialized and urbanized under communism, for example, relative incomes did not increase. While East Central European incomes per capita averaged 37 percent of West European per capita incomes in the prewar 1930s, this proportion dropped slightly to an average of 35 percent by the 1970s and $1980 \mathrm{~s} .{ }^{65}$ Even where material conditions improved under communism, as in Slovakia and Western Ukraine, the hostility to communism continued unabated.

At the same time, as Bunce and Kopstein and Reilly point out, geographic proximity meant constant and invidious comparisons to neighboring countries. For Czechs, Slovaks, Slovenians, and Hungarians, the proximity of Austria (and their shared historical past) was one benchmark against which their countries could be measured-and their postwar development was found to be wanting. The availability of Austrian and German media broadcasts in the border regions only accentuated the shortcomings of the socialist system. For Estonians and Latvians, Finland provided the comparison. Romanian intellectuals looked to France, whereas for Polish dissidents, Scandinavia provided an alternative model. ${ }^{66}$ As a result, even though communism produced a massive economic and societal transformation with some positive effects, particularly in developing rural areas, such achievements were discounted in comparison with the counterfactual of noncommunist statehood and the ready comparisons with the West. As one observer noted, the prevailing sentiment was that "if not for communism, we would have been like the West." ${ }^{67}$

${ }^{65}$ Figures calculated from Janos (fn. 12), 349.

${ }^{66}$ A 1970s joke plaintively asked, "Why did the Black Madonna fight back the Swedish onslaught? We could have been Sweden..."

${ }^{67}$ Adam Przeworski, Sustainable Democracy (New York: Cambridge University Press, 1995), 3. 
The same dynamics appear in those nations of the former Soviet Union that had received mass schooling prior to the advent of communism. In Georgia communism was seen as alien and violently imposed during the Bolshevik annexation of the Transcarpathian republic in 1921 and the repression of the Georgian uprising in 1924. In the 1920s and 1930s senior Soviet officials (including Stalin himself) recognized that Georgians refused to accept the legitimacy of Soviet communism, especially in Western Georgia. ${ }^{68} \mathrm{~A}$ detailed ethnographic account from the 1970s from the Abari and Likheti regions found that even rural residents romanticized their precommunist past, schooled their children at home in precommunist national myths, and viewed Russian and Soviet culture as inferior. ${ }^{69}$ Sentiments in Armenia tended to be more pro-Russian, because in precommunist Armenian myth, Russians were depicted as providing Armenians with a haven from their historical oppressors, the Turks.

In Estonia, Latvia, Lithuania, and the areas of Ukraine that had national schooling prior to their incorporation into the USSR, anti-Russian sentiments were- and remain-pervasive. Even though the USSR brought industrialization and electrification to rural areas, communism never achieved broad popular support; indeed, it was seen as undermining the more progressive European character of these regions. And nationalist views were expressed in underground publications despite the ruthless suppression of any public expression of anticommunist sentiment. In Ukraine these regions had considerably higher levels of arrests of nationalist dissidents in the $1960 \mathrm{~s}$ and $1970 \mathrm{~s}^{70}$ And as in Georgia, a parallel underground culture existed alongside official Soviet life that consisted of anticommunist histories, literature, and songs. Significant religious or national holidays were celebrated privately and the underground culture was passed on in private gatherings of family and friends. Communism was seen as forcibly imposed by Russian (or "Muscovite" in the Ukrainian case) occupation, and the horrors of Soviet annexation in 1939 and then 1944 were recounted to show the nonindigenous, ethnically Russian (or Jewish) nature of communist rule. Local communists were viewed as collaborators with an occupying power. Only anticommunist activities were considered patriotic and loyal.

By contrast, in Central Asia and Azerbaijan the comparisons with both the pre-Soviet past and the noncommunist neighboring states were

${ }^{68}$ Tamara Dragadze, Rural Families in Soviet Georgia (New York: Routledge, 1988).

${ }^{69}$ Ibid., 183-84

${ }^{70}$ Kenneth C. Farmer, Ukrainian Nationalism in the Post-Stalin Era: Myth, Symbols and Ideology in Sorviet Nationalities Policy (Boston: Martinus Nijhoff, 1980), 176-79. 
highly favorable. Communism, closely linked to the Soviet Union, was identified with enlightenment and progress, rather than with forced imposition. Communism was credited with bringing electrification, industry, schooling and high culture, and all forms of modern life to the region. It was associated in particular with the liberation of women from the oppression of traditional life. In Central Asia primary identification appears to have been with the communist-era administrative units (oblasts), rather than with clans, tribes, or any real or imagined precommunist community. ${ }^{71}$ The precommunist past was seen in the late 1980s and the 1990s largely as it had been depicted in Soviet accounts, as a world of ignorance, superstition, and poverty. ${ }^{72}$ Even as specific policies from Moscow could be subject to criticism, the general assessment was that Soviet rule had brought dramatic improvement to the lives of Central Asians. Russians and their cultural impact on the region were viewed in a very positive light. ${ }^{73}$

For the Central Asian states, comparisons with their neighbors confirmed their favorable view of the impact of communism. Today, Afghanistan and Pakistan still represent examples of life without communism. Afghanistan under the Taliban fit precisely the Soviet stereotype of precommunist life. Only neighboring China is viewed in a favorable light, but as a communist country the Chinese example simply reinforces the general view equating communism with the forces of enlightenment and modernity in the region. Indeed, it is typically viewed as the counterfactual "path not taken," that is, what life might be like had communism not ended with the USSR.

In areas of Ukraine, Belarus, and Moldova schooled by the Soviets -much like Central Asia-pro-Russian sentiments predominated and continue to predominate. Consistent with Soviet ideology, communism is associated with technology, industry, and progress. Even in the areas of Ukraine hit hardest by the famine during collectivization, communism is credited with bringing the mechanization of agriculture, literacy, and progress. Indeed, surveys indicate that these areas are the most staunchly

${ }^{71}$ See Jones Luong (fn. 11), chap. 3.

72 The same depictions of the positive impact of communist rule depicted in the 1920s propaganda film, Three Songs for Lenin (Dziga Vertov), were repeated in many conversations with Central Asian respondents in the mid-1990s.

${ }_{73}$ According to State Department surveys conducted through the 1990 s, the share of respondents with a "favorable" opinion of Russia in 1994 was 74 percent in Azerbaijan, 78 percent in Kazakhstan, 86 percent in Uzbekistan, 83 percent in Kyrgyzstan, 90 percent in Armenia (up from 43 percent in 1992), but only 36 percent in Georgia. See Regina Faranda, "Ties That Bind, Opinions That Divide" (Manuscript, U.S. State Department Opinion Surveys, 2001); see also David D. Laitin, Identity in Formation: The Russian-Speaking Nationality in Estonia and Basbkortostan (Glasgow: Centre for the Study of Public Policy, University of Strathclyde, 1995). 
pro-Russian and most nostalgic for the Soviet system. ${ }^{74}$ Communism was also viewed as an indigenous movement in these regions, with local communist heroes lionized and considered to be true patriots. While Ukrainians and Belarussians see themselves as having a distinct identity and culture, this culture is viewed as closely related and equal to or inferior to the literature and art of the broader Russian community. The collective effort to defend the Soviet Union from Nazi aggression is considered the major patriotic achievement of the local populations and the Communist Party, especially in Belarus. Communist partisans and Red Army soldiers were viewed as defenders of the motherland, not as an occupying force. ${ }^{75}$

\section{From Comparisons to OpPosition}

These widespread comparisons meant that the appeals of nationalist opposition elites would find different levels of resonance among the populace. Across the communist world, elite groups were opposed to communist rule, criticizing it on nationalist and cultural grounds. However, whether or not such critiques would find broad popular support depended on extant national sentiment and identity. Where nationalist schooling existed, anticommunist opposition resonated with popularly held notions of communism as an alien and antimodern imposition. Such opposition took the form of highly organized mass movements, such as Solidarity in Poland in 1980 (with over ten million members, or one-third of the adult population) or the smaller but similarly recognizable opposition groups in Hungary. In Slovenia a nationalist communist leader, Milan Kučan, assumed power in 1986 and led the republic to greater independence from the Yugoslav federation, culminating in the 1990 elections of DEMOS, a six-party opposition coalition that had arisen in the late $1980 \mathrm{~s}$.

The anticommunist opposition, whether organized or still inchoate, made explicit references to the prewar past. Prewar national holidays, such as August 17 (the anniversary of the Battle of Vistula during the Bolshevik War) or May 3 (the 1792 constitution) were occasions for Poles to fly the Polish flag on their houses and balconies. ${ }^{76}$ March 15,

${ }^{74}$ In 1994, 81 percent of respondents in Ukraine and 88 percent in Belarus took a favorable view of Russia, and these figures were consistent throughout the 1990s. Only 27 percent of respondents in Western Ukraine viewed Russia as an ally; Faranda (fn. 73), 44.

${ }_{75}$ Andrew Wilson, Ukrainian Nationalism in the 1990s: A Minority Faith (New York: Cambridge University Press, 1997); Karel C. Berkhoff, Harvest of Despair: Life and Death in Ukraine under Nazi Rule (Cambridge: Harvard University Press, 2004), 206-13.

${ }^{76}$ See Jan Kubik, The Power of Symbols against the Symbols of Power (Pittsburgh: Pennsylvania State University Press, 1994); Janine Wedel, The Private Poland (New York: Facts on File Publications, 1986). 
the anniversary of the 1848 revolution in Hungary, was similarly celebrated with marches and slogans, many of which took on an anticommunist cast. In 1989, when the opposition's demonstration was five times larger than the Hungarian communists' official observance, the holiday confirmed the public rejection of the communist regime. ${ }^{77}$

Where the communist regime had been more repressive but schooling had inculcated nationalist identities, the opposition consisted of ad hoc coalitions of mass movements uniting behind elites in the last days of the communist regime. Thus, in Czechoslovakia, mass opposition groups, Public against Violence and Civic Forum, arose only in the days and weeks before the communist collapse. The Czechoslovak case also shows that the communists may be forced to exit in face of popular hostility, even where no entrenched organization of dissent exists. The ultimate cause for the communist exit is the popular sentiment engendered by nationalist schooling and the comparisons it breeds, rather than the power of elite organization itself. Conversely, Communist Party strategies may shape the form of the protests, but they do not determine the party's legitimacy or the extent of its delegitimation.

Once communism began to collapse, these forces revived prewar democratic parties (the Polish PPS, Czech Social Democrats, Hungarian Smallholders'), resuscitated prewar party acronyms (the Polish BBWR), and adopted historical institutional solutions (parliamentary systems or prewar constitutions, which were initially adopted wholesale by the new postcommunist governments in the Baltic Republics). The essence of the opposition project was encapsulated in the slogan of a "Return to Europe," as the motivation for the enormous project of democratization, market reforms, and social transformation that followed. ${ }^{78}$ This is not to say the prewar period was idolized without reservations or without awareness of its obvious flaws: but much of the opposition saw the communist collapse and the possibility of establishing new domestic forms of rule as a return to "normalcy," the natural state of these nations. $^{79}$

In the former Soviet Union internal variation corresponds precisely to precommunist nationalist schooling. Popular anticommunist opposition movements appeared in the three Baltic states, Moldova, Georgia, and Western Ukraine and amassed demonstrations of over one hundred 318.

${ }^{77}$ Rudolf Tökes, Hungary's Negotiated Revolution (Cambridge: Cambridge University Press, 1986),

${ }^{78}$ Even the 1989 slogan for Kučan's extremely liberal Slovene communists was "Europe Now!"

${ }^{79}$ See Padraic Kenney, A Carnival of Revolution (Princeton: Princeton University Press, 2002). 
thousand people, in many cases already as early as $1988 .{ }^{80}$ In each of these cases the movement organizers laid out an explicit nationalist agenda that drew on banned precommunist flags and symbols (the flags of the interwar period in the Baltics, the blue-and-yellow flag and trident in Western Ukraine, the Georgian flag from 1918, and the flag and symbols of interwar Romania in Moldova). The largest protests typically took place on dates of symbolic significance in the precommunist national calendar, such as dates of independence. One of the first large-scale demonstrations, for example, held on May 28, 1988, in Armenia by the Association for National Self-Determination, marked the sixtieth anniversary of precommunist Armenia's date of independence in $1918 .{ }^{81}$ Consistent with our claims, Karklins argues that such "calendar demonstrations," as they were called in the Baltics, rested on a shared cultural knowledge that "facilitated mobilization by reducing the need for formal communication." ${ }^{22}$ Banned precommunist anthems, nationalist songs, or songs from the wartime anticommunist partisans - known to all-were also used to mobilize mass protests. ${ }^{83}$ The movements also demanded revision of communist historical narratives (surrounding the Molotov-Ribbentrop pact in the Baltic case) and the protection of important national or religious sites (the Davitgaredzha monastery in Georgia) ${ }^{84}$ In each of these countries, anticommunist opposition was broad based, took the form of a nationalist movement, and drew on precommunist myths, symbols, and rituals.

These movements channeled directly into political organizations that defeated the Communist Party in the first set of free elections in 1990. In Georgia nationalist organizations such as the Chavchavadze society coalesced into the Free Georgia movement, led by the nationalist dissident Zviad Gamsakhurdia. The movement drew explicitly on Georgia's heroic pre-Soviet past (Chavchavadze was a prominent nineteenth-century nationalist writer). Gamsakhurdia's nationalist agenda decried mixed marriages and even Soviet industrial advancements such

\footnotetext{
${ }^{80}$ As these movements and the manner in which they drew on precommunist national symbols and dates of significance to mobilize the population are demonstrated in detail by Beissinger, we will give only a brief overview here. See Mark R. Beissinger, Nationalist Mobilization and the Collapse of the Soviet State (Cambridge: Cambridge University Press 2002), chap. 4.

${ }^{81}$ Beissinger (fn. 80),187.

${ }^{82}$ Rasma Karklins, Ethnopolitics and Transition to Democracy: The Collapse of the USSR in Latvia (Washington, D.C.: Woodrow Wilson Center Press, 1994), 94-95, cited in Beissinger (fn. 80), 169.

${ }^{83}$ In Estonia, for example, the "singing revolution" replicated the national singing festivals of the late nineteenth century, singing precommunist songs and mobilizing as much as a third of the population into demonstrations calling for independence; Beissinger (fn. 80), 172. Robert Person, "Resisting Hegemony: Transformations in Estonian Identity under Soviet Rule" (Manuscript, Yale University, 2005).

${ }^{84}$ Beissinger (fn. 80), 180.
} 
as the "building of gigantic hydro-electric power stations and enterprises" as "a manifestation of an ecological war against Georgia and in the end its aim was the genocide of its people," and it attacked the importation of Soviet engineers to run the factories as part of a plan for the forced assimilation of Georgia. ${ }^{85}$

In Armenia the nationalist movement to unite the Nagorno-Karabakh region of Azerbaijan with Armenia repeatedly drew crowds in the tens of thousands to the streets in the late 1990s. The de facto leader of the Karabakh committee, Levon Ter-Petrosian, a nationalist linguist born outside the USSR, drew on historical myths of a greater Armenia to legitimate claims to Karabakh. With the first free elections in 1990, Ter-Petrosian and the Karabakh committee rode to power easily and Ter-Petrosian became head of state. In all three Baltic states the national movements rapidly developed political organizations with broad popular appeal (ENIP, the Estonian Popular Front, and the defection of a proindependence group from the ECP in Estonia, Sajudis in Lithuania, and the Latvian Popular Front). Each of these swept the communists from power in the Supreme Soviet elections in 1990. In Ukraine, despite considerable repression from the hard-line communist leadership in Kiev, massive nationalist demonstrations in the provincial capitals of Galicia (Lvov, Ivano-Frankovsk, Ternopol) led to the formation of Rukh, which took control of these local governments in the 1990 elections and took all of the elected seats from these regions to the Supreme Soviet elections of $1990 .^{86}$ In other Ukrainian provinces the Communist Party safely and comfortably held on to power, even in Transcarpathia, which had also been incorporated into the USSR after World War II. It was only in those Ukrainian provinces that had precommunist national schooling that the communists were voted out of power. What was true for Ukraine was true for the Soviet Union as a whole: where mass schooling was introduced under communism, the communists held on to power in the elections of 1990.

Where no nationalist schooling took place, there was no pool of national sentiment from which elites opposing the communist regimes could draw. Even where prominent opposition figures existed, such as Mihai Botez, Doina Cornea, and Mircea Dinescu in Romania, they were unable to foment the kind of mass opposition to communist rule that was the immediate cause of the communist collapse. Without the groundswell of demands for their exit, Romanian communists were

\footnotetext{
${ }^{85}$ Zviad Gamsakhurdia, "Open Letter to Eduard Shevardnadze," translated from the Russian by the Zviad Gamsakhurdia Society in the Netherlands, April 19, 1992.

${ }^{86}$ Beissinger (fn. 80), 194-98; Wilson (fn. 75).
} 
able to hold on to power as their counterpart regimes fell. Their internal coup of $1989 \mathrm{kept}$ them in power until the 1996 first free elections, which forced them out. Similarly, the communists in Albania held on to power through the elections of April 1991 with over 56 percent of the vote, leaving office only in May 1992.

Bulgaria appears at first to be an exception to the correlation between nationalist schooling and the communist exit: despite the introduction of Bulgarian national schooling (albeit one that was strongly pro-Russian and pro-Soviet, given the Russian liberation of Bulgaria in 1905), the Communist Party formed the government after the first free elections in 1990, with 47 percent of the vote. ${ }^{87}$ It is important to note, however, that the combined anticommunist opposition actually won more votes, with 50 percent: the Union of Democratic Forces, the main opposition movement, received 36 percent of the vote, the Bulgarian National People's Union (a throwback to prewar agrarian parties) received 8 percent, and the Turkish minority opposition party, 6 percent.

In short, nationalist schooling produced shared expectations and standards for a legitimate government. It sustained both anticommunist sentiment throughout the postwar era and the opposition that arose (and organized where the communist regime made it possible). The overwhelming and shared desirability of a "return to normalcy" produced an elite consensus about the need for a new and noncommunist regime, even if, as the cases of Slovakia, Croatia, Georgia, and Armenia show, elite commitments to democracy itself were far shakier. As Valerie Bunce points out, nationalism is "wanton" and can coexist with both democratic and authoritarian regimes. It is the content of nationalism, not its advocacy of uniting political and administrative units, that determines whether it serves as a force for consolidating democracy or for undermining liberal rule. ${ }^{88}$

\section{Conclusion}

To lengthen and deepen the causal chain behind the patterns of communist exit from power, we argued that precommunist nationalist schooling produced the shared memories and standards that made popular acceptance of communist rule unlikely. Constant comparisons to both the prewar era of independence and to neighboring noncom-

\footnotetext{
${ }^{87}$ They then exited office after their government collapsed in November 1991.

${ }^{88}$ See Milada Anna Vachudová and Timothy Snyder, "Are Transitions Transitory? Two Models of Political Change in East Central Europe since 1989," East European Politics and Societies 11 (Winter 1997)
} 
munist countries meant that where nationalist schooling existed, such comparisons would strengthen anticommunist convictions. As a result, decades of these comparisons under communism led to the rise of widespread opposition to communist rule (whether highly organized or not). In a much shorter causal link, this opposition then led to the communist exit, both because communist rule had been discredited and because the opposition provided a salient and far more legitimate governing alternative. By contrast, where schooling was introduced under communism, no such invidious comparisons were made. Rather, the shared understanding was that communist rule brought modernity and its attendant advancements.

The communist exit pinpoints which factors identified by earlier modernization analyses changed popular values and expectations regarding good governance. While education, economic development, and urbanization were bundled together by these earlier analyses, we show that it was mass schooling-and the national content it transmitted-that influenced the degree to which communist rule was viewed as legitimate (or not) and the subsequent mobilization against it. Other factors may correlate with each other, but they do not explain the developments in the communist world or the eventual trajectories of its collapse.

The timing and content of schooling explain more variation than do the alternative models, while also complementing them. The account presented here elaborates the underlying mechanisms of geographic proximity and prewar legacies and shows why the anticommunist opposition arose in the first place. The key to these extensions and to the causal chain behind the communist exit is the reincorporation of the microfoundations of individual and societal behavior: the shared understandings, expectations, and standards for legitimate government. These notions are why anticommunism was equated with nationalism (even if not always with democracy). National identities may have also helped to propel these countries through the troughs of painful market reforms and confusing political change, generating popular acceptance of the sacrifices necessary. This, then, may be one way in which "culture matters"-not as a structural predisposition for particular behaviors or as an affinity for specific institutional solutions but as a historically created set of widely shared standards for government origin, legitimacy, and performance. 


\section{APPENDIX 1}

LITERACY AND COMMUNIST EXIT

\begin{tabular}{|c|c|c|c|c|c|c|}
\hline & $\begin{array}{l}\text { iteracy Rate } \\
\text { at Onset } \\
\text { f Communist } \\
\text { Schooling }\end{array}$ & $\begin{array}{cc} \\
\text { Precommunist } \\
\text { No } \\
\text { Curricular } \\
\text { Content }\end{array}$ & $\begin{array}{l}\quad \% \\
\text { Noncommunist } \\
\text { Seats in First } \\
\text { Free Elections } \\
\end{array}$ & $\begin{array}{l}\text { Precommunist } \\
\text { Urbanization }\end{array}$ & $\begin{array}{c}\text { Years of } \\
\text { Democratic } \\
\text { Statebood } \\
\text { Precomm }\end{array}$ & \\
\hline \multicolumn{7}{|l|}{ Czech } \\
\hline Republic & 99 & National & 84 & 25 & 20 & 1 \\
\hline Estonia & 99 & National & 74.3 & 33 & 14 & 0 \\
\hline Hungary & 96 & National & 83.2 & 42.5 & 4 & 1 \\
\hline Latvia & 93 & National & 73 & 36 & 14 & 0 \\
\hline Slovakia & 92 & National & 85 & 15 & 20 & 1 \\
\hline Slovenia & 91 & National & 87 & 9.3 & 8 & 1 \\
\hline Poland & 79 & National & 87 & 20 & 8 & 1 \\
\hline Lithuania & 77 & National & 67.3 & 15 & 4 & 1 \\
\hline \multicolumn{7}{|l|}{ W. Ukraine } \\
\hline (Galicia) & 70 & National & 95.7 & 23.2 & 8 & 0 \\
\hline Bulgaria & 69 & National & 48 & 21 & 0 & 1 \\
\hline Croatia & 68 & National & 75 & 9.3 & 8 & 1 \\
\hline Georgia & 65 & National & 74 & 22 & 0 & 0 \\
\hline Romania & 57 & National & 33 & 21 & 0 & 1 \\
\hline Armenia & 56 & National/Russian & 89.8 & 19 & 0 & 0 \\
\hline Moldova & 46 & Romanian & 54.4 & 16 & 0 & 0 \\
\hline E. Ukraine & 46 & Russian/Russophile & 13.9 & 19 & 0 & 0 \\
\hline Russia & 44 & Russian & 14 & 17 & 0 & 0 \\
\hline \multirow[t]{2}{*}{ Belarus } & 42 & W-Polish/Russian & & & & \\
\hline & & E-Russian & 21 & 19 & 0 & 0 \\
\hline Serbia & 35 & National & 22.4 & 9.3 & 8 & 1 \\
\hline Macedonia & 30 & Bulgarian, Serbian & 74.7 & 9.3 & 8 & 1 \\
\hline Bosnia- & & Bosniak/Yugoslav, & & & & \\
\hline Herzegovina & 28 & Croat, Serb & 79.2 & 9.3 & 8 & 1 \\
\hline Albania & 20 & Religious & 32 & 13 & 5 & 1 \\
\hline Azerbaijan & 20 & Russian & 22.2 & 28 & 0 & 0 \\
\hline Kazakhstan & 18 & Russian & 5.6 & 9 & 0 & 0 \\
\hline Kyrgyz Republic & lic 12 & Russian & 0 & 12 & 0 & 0 \\
\hline \multirow[t]{2}{*}{ Uzbekistan } & 11 & Russian, some & & & & \\
\hline & & Turkic/Arabic & 5 & 22 & 0 & 0 \\
\hline Turkmenistan & 10 & Russian & 5 & 14 & 0 & 0 \\
\hline Tajikistan & 4 & Russian & 5 & 10 & 0 & 0 \\
\hline
\end{tabular}




\section{APPENDIX 2: OpERATIONALIZATION}

\section{COMMUNIST EXIT}

We use the share of parliamentary seats taken by noncommunist candidates in the first free elections. We measure seats because (1) in the post-Soviet cases the share of the vote for different candidates is not available and (2) the share of the seats is a more direct measure of whether the communists were able to hold on to power, which is the variable of interest. The results, however, are robust to both specifications of the communist exit as seats and as share of the votes.

The first free elections in the ECE cases were all held in 1990-91. For the Yugoslav and Soviet cases, the first free elections were held while those federations still formally existed, so we use elections to the republican bodies in each case. For the post-Soviet countries, the first free elections were the elections to the Republican Supreme Soviets in the spring of 1990 . The Communist Party had ceased to hold a legal monopoly on power, the media were quite free and diverse, all residents were allowed to vote, there were few restrictions placed on the nomination of candidates or political mobilization, and, with the exception of Russia, the rules and institutions were standard across all of the republics. After spring of 1990 many of these countries never held another free election, subsequently denied the vote to a substantial share of the populations, or banned the Communist Party.

\section{Precommunist Literacy}

We use the precommunist literacy rate. With the exception of Georgia and Armenia, this is simply the literacy rate at the time the communists took power. For Georgia and Armenia we use the literacy rate in 1933, the year that the Communist Party began to replace the precommunist nationalist school curriculum.

\section{National Content}

In several cases the precommunist schooling did not cultivate titular nationalism. Macedonians were educated in Serbo-Croatian and told they were Serbs. Most schools in the Russian Empire were Russophone and Russophile. For example, Russian was the language of schools in Belarus and Ukraine, and students were taught that they were Russian. For this reason, we also code a dichotomous variable to identify titular national content of the precommunist education. 


\section{Precommunist Urbanization}

Given the difficulties of calculating GDP, particularly at a provincial level, we use urbanization-the share of the population living in cities and towns-as a proxy variable to control for the level of economic development at the onset of communism. Urbanization is strongly correlated with industrialization: the correlation between urbanization and industrialization is .885 across countries with over million inhabitants in $1945 .{ }^{89}$ In the precommunist world the development of industry coexisted with a large rural population that remained active in agriculture, and urbanization rates significantly lagged behind West European rates. ${ }^{90}$ Some industries such as textiles in the Bohemian lands, were also located in the countryside. ${ }^{91}$ Nonetheless, the urban centers were the epitome of modern society, "the home and the symbol of industry, commerce, and powerful banks."

\section{YeARS OF Democratic STATEHOOd}

We follow Kitschelt and use the number of years of independent democracy prior to the onset of communist rule.

\section{DisTANCE FROM WEST}

We replicate the coding from Kopstein and Reilly, ${ }^{93}$ measuring the distance from the capitals to either Berlin or Vienna (whichever is closer.) In the case of Ukraine, we used Kyiv as the capital of East Ukraine, and Lviv as the capital of West Ukraine.

${ }^{89}$ Thomas Wilkinson, "Urban Structure and Industrialization," American Saciological Review 25 (June 1960), 357. Urbanization here is defined as the proportion of the population residing in politically defined cities.

${ }^{90}$ See Ivan Szelenyi, "Urban Development and Regional Management in Eastern Europe," Theory and Society 10 (March 1981), 180. Iván Berend and György Ránki, Economic Development in East-Central Europe in the $19^{\text {th }}$ and $20^{\text {th }}$ Century (New York: Columbia University Press, 1974), 154.

${ }^{91}$ Gale Stokes, "The Social Origins of East European Politics," in Daniel Chirot, ed., The Origins of Backwardness in Eastern Europe (Berkeley: University of California Press, 1989), 217.

${ }_{92}^{92}$ Berend and Ránki (fn. 90), 310.

${ }^{93}$ Kopstein and Reilly (fn. 5 ). 